\title{
Lack of association between three common genetic variations of XPC and susceptibility to age-related macular degeneration, a preliminary study
}

\author{
Sharareh Kalteh and Mostafa Saadat ${ }^{*}$
}

\begin{abstract}
Background: Numerous association studies have indicated that genetic alterations in genes involved in DNA repair processes are associated with the risk of age-related macular degeneration (ARMD). There is no published study on the relationship between common xeroderma pigmentosum complementation group C (XPC, MIM 613208) polymorphisms and susceptibility to ARMD. The aim of this study is to determine whether three common (Ala499Val, Lys939GIn, and PAT) genetic variants of XPC are associated with the risk of developing ARMD. A total of 120 ARMD patients and 118 healthy controls were included in the study. Genotyping analyses were carried out by PCR-based methods.
\end{abstract}

Results: Our analysis revealed that there was no relationship between the XPC polymorphisms and susceptibility to ARMD. In both case and control groups, strong linkage disequilibrium existed between three common (Ala499Val, Lys939GIn, and PAT) genetic polymorphisms of XPC. Statistical analysis showed no association between the haplotypes and the risk of ARMD.

Conclusions: The present data indicated that the common polymorphisms of XPC are not susceptible genetic variations for ARMD.

Keywords: DNA repair, Linkage disequilibrium, Macular degeneration, Polymorphism, XPC, Risk

\section{Background}

Age-related macular degeneration (ARMD) is a multifactorial complex disease. The photoreceptor degeneration in the central part of the retina leads to the complete loss of central vision. Although the etiology of ARMD is not understood, previous studies have indicated the reactive oxygen species (ROS)-induced damage in ARMD patients $[1,2]$. The retina has high level of oxygen consumption. It is revealed that photochemical reactions between light and $\mathrm{O}_{2}$ lead to the production of $\operatorname{ROS}[3,4]$. It is well established that ROS can damage cellular macromolecules including DNA. The impaired efficacy of

\footnotetext{
* Correspondence: saadat@shirazu.ac.ir

Department of Biology, College of Sciences, Shiraz University, Shiraz, Iran
}

cellular DNA repair might contribute to the pathogenesis of ARMD [5-7].

Xeroderma pigmentosum complementation group $\mathrm{C}$ (XPC, MIM 613208) encodes a protein which is involved in nucleotide excision repair by initially detecting the DNA damage [8]. In human populations, the XPC has several common polymorphisms including Ala499Val (rs2228000), Lys939Gln (rs2228001), and PAT [9, 10]. It should be noted that these polymorphisms are associated with cellular DNA repair capacity [11]. Studies have indicated that these polymorphisms are associated with the risk of several multifactorial traits such as cancers [12-15], schizophrenia [16], and dependency to drugs [17].

A meta-analysis of genome wide linkage studies has confirmed that the human chromosome $3 p$ is a

\section{Springer Open}

(c) The Author(s). 2020 Open Access This article is licensed under a Creative Commons Attribution 4.0 International License, which permits use, sharing, adaptation, distribution and reproduction in any medium or format, as long as you give appropriate credit to the original author(s) and the source, provide a link to the Creative Commons licence, and indicate if changes were made. The images or other third party material in this article are included in the article's Creative Commons licence, unless indicated otherwise in a credit line to the material. If material is not included in the article's Creative Commons licence and your intended use is not permitted by statutory regulation or exceeds the permitted use, you will need to obtain permission directly from the copyright holder. To view a copy of this licence, visit http://creativecommons.org/licenses/by/4.0/. 


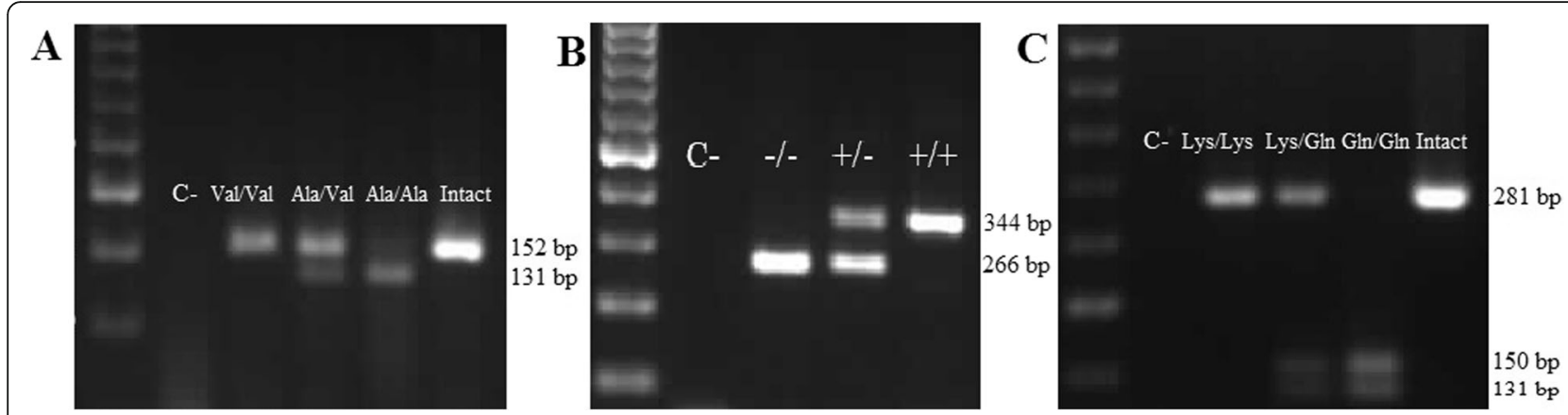

Fig. 1 Genotyping analyses for three common (Ala499Val, Lys939GIn, and PAT) genetic variants of XPC. a-c Showed the genotypes of the Ala499Val, PAT, and Lys939GIn polymorphisms, respectively. In each panel line, "C-" means "negative control"; lines "Intact" showed the PCR product before digestion with restriction enzyme

candidate chromosome segment associated with the ARMD [18]. It should be noted that the gene encoding $X P C$ is located on human chromosome 3p25.1 [19]. Previously, the association between common genetic polymorphisms of genes involved in DNA repair processes and susceptibility to ARMD has been reported [20-25]. Taken together, it is concluded that the XPC might be associated with the susceptibility to ARMD. As there is no published study on the association between common $X P C$ polymorphisms and susceptibility to ARMD, this case-control study was carried out.

\section{Methods}

This hospital-based case-control study consisted of 120 patients (75 males, 45 females) with exudative ARMD. The patients were recruited from the "Khalili Hospital Ophthalmic clinic" (Fars province, Iran), referred by a vitreoretinal surgeon. Moreover, 118 gender frequencymatched participants (68 males, 50 females) were randomly selected from unrelated volunteers in the same clinic and used as the control group. The mean age (SD) of the ARMD patient and the control groups was 69.6 (9.7) and 63.5 (10.0) years, respectively. There was significant difference in age distribution between the patients and the controls $(t=4.73, \mathrm{df}=236, P<0.001)$. Based on the job titles, the participants were categorized into indoor (teachers, housewives, etc.) and outdoor (drivers, farmers, etc.) groups. The outdoor participants were occupationally exposed to sunlight. In the present study, the participants were selected from the same ethnical group (Muslims/Persians) living in Shiraz. This casecontrol study was approved by the local ethics committee. Informed consent was obtained from all participants.

Genotyping analyses for the Ala499Val (rs2228000) and Lys939Gln (rs2228001) polymorphisms were carried out using specific primers as described previously $[9,10]$ for the polymerase chain reaction restriction fragment length polymorphisms (PCR-RFLP). The PAT polymorphism is an insertion of 83 bases of A and T [poly (AT)] with a 5- base deletion (GTAAC at position 1457-1461, GenBank Accession No. AF076952) within intron 9 of the XPC gene [26]. Therefore, PCR products of the Ins and Del alleles have different lengths (Fig. 1). Genotyping for this polymorphism was carried out using specific primers as described previously in a simple PCR [10].

For each study polymorphisms, the observed genotypic frequencies were compared with the expected frequencies based on the Hardy-Weinberg equilibrium (HWE). Unconditional binary logistic regression analysis was used to estimate odds ratios (ORs) and 95\% confidence intervals (CIs) for ARMD risk associated with the genotypes of the study polymorphisms. Considering the significant age difference between the cases and the controls, in further analysis, logistic regression was used to estimate ORs and 95\% CIs for the various genotypes after adjusting for age. Genetic linkage

Table 1 The general characteristics of age-related macular degeneration patients and the healthy control group

\begin{tabular}{|c|c|c|c|c|}
\hline & Control & Case & $x^{2}(d f=1)$ & $P$ \\
\hline \multicolumn{5}{|l|}{ Gender } \\
\hline Females & 50 & 45 & 0.58 & 0.443 \\
\hline Males & 68 & 75 & & \\
\hline \multicolumn{5}{|l|}{ Smoking habit } \\
\hline Non-smoker & 64 & 68 & 5.76 & 0.016 \\
\hline Smoker & 18 & 42 & & \\
\hline Missing & 36 & 10 & & \\
\hline \multicolumn{5}{|l|}{ Workplace } \\
\hline Indoor & 66 & 66 & 6.21 & 0.013 \\
\hline Outdoor & 26 & 54 & & \\
\hline Missing & 26 & 0 & & \\
\hline \multicolumn{5}{|l|}{ Hypertension } \\
\hline No & 105 & 112 & 1.03 & 0.309 \\
\hline Yes & 4 & 8 & & \\
\hline Missing & 9 & 0 & & \\
\hline Age & $63.5 \pm 10.0$ & $69.9 \pm 9.7$ & $t=4.76, \mathrm{df}=236$ & $<0.001$ \\
\hline
\end{tabular}


disequilibrium between the alleles of the $X P C$ polymorphisms was estimated using the SNPAlyze (TM) software (ver. 6 Standard, Dynacom Co, Ltd. Kanagawa, Japan). A $P$ $<0.05$ was considered a statistically significant difference.

\section{Results}

The general characteristics of the ARMD patients and the control group are summarized in Table 1. In our study subjects, $45.0 \%$ (out of 120) of the patients and $28.3 \%$ (out of 92) of the healthy controls had outdoor jobs. This difference was statistically significant $\left(\chi^{2}=\right.$ $6.21, \mathrm{df}=1, P=0.013)$. Among the ARMD patients and the controls, $38.2 \%$ (out of 110) and $22.0 \%$ (out of 82 ) were smokers $\left(\chi^{2}=5.76, \mathrm{df}=1, P=0.016\right)$, respectively.

Table 2 summarized the genotypic frequency of the three common XPC polymorphisms among the ARMD

Table 2 The association between three common XPC polymorphisms and the risk of age-related macular degeneration

\begin{tabular}{|c|c|c|c|c|c|c|c|c|}
\hline Polymorphisms/genetic models & Controls & Cases & OR & $95 \% \mathrm{Cl}$ & $P$ & $\mathrm{OR}^{*}$ & $95 \% \mathrm{Cl}$ & $P$ \\
\hline \multicolumn{9}{|l|}{ PAT } \\
\hline \multicolumn{9}{|l|}{ Additive model } \\
\hline$-/-$ & 33 & 31 & 1.0 & - & - & 1.0 & - & - \\
\hline$-/+$ & 57 & 60 & 1.12 & $0.61-2.06$ & 0.714 & 1.11 & $0.58-2.11$ & 0.746 \\
\hline$+/+$ & 28 & 29 & 1.10 & $0.54-2.25$ & 0.789 & 0.92 & $0.44-1.95$ & 0.846 \\
\hline \multicolumn{9}{|l|}{ Dominant model } \\
\hline$-/-$ & 33 & 31 & 1.0 & - & - & 1.0 & - & - \\
\hline$-/+$ and $+/+$ & 85 & 89 & 1.11 & $0.62-1.97$ & 0.711 & 1.04 & $0.57-1.91$ & 0.881 \\
\hline \multicolumn{9}{|l|}{ Recessive model } \\
\hline$-/-$ and $-/+$ & 90 & 91 & 1.0 & - & - & 1.0 & - & - \\
\hline$+/+$ & 28 & 29 & 1.02 & $0.56-1.85$ & 0.937 & 0.86 & $0.46-1.61$ & 0.653 \\
\hline Minor allele frequency & 0.4788 & 0.4917 & 1.05 & $0.73-1.50$ & 0.779 & & & \\
\hline \multicolumn{9}{|l|}{ Ala499Val } \\
\hline \multicolumn{9}{|l|}{ Additive model } \\
\hline Ala/Ala & 72 & 73 & 1.0 & - & - & 1.0 & - & - \\
\hline Ala/Nal & 41 & 39 & 0.93 & $0.54-1.62$ & 0.819 & 1.02 & $0.57-1.81$ & 0.947 \\
\hline Val/Nal & 5 & 8 & 1.57 & $0.49-5.05$ & 0.442 & 1.48 & $0.45-4.92$ & 0.515 \\
\hline \multicolumn{9}{|l|}{ Dominant model } \\
\hline Ala/Ala & 72 & 73 & 1.0 & - & - & 1.0 & - & - \\
\hline $\mathrm{Ala} / \mathrm{Nal}+\mathrm{Val} / \mathrm{Val}$ & 46 & 47 & 1.01 & 0.59-1.69 & 0.977 & 1.07 & $0.62-1.86$ & 0.791 \\
\hline \multicolumn{9}{|l|}{ Recessive model } \\
\hline $\mathrm{Ala}+\mathrm{Ala} / \mathrm{Nal}$ & 113 & 112 & 1.0 & - & - & 1.0 & - & - \\
\hline Val/Nal & 5 & 8 & 1.61 & $0.51-5.08$ & 0.413 & 1.47 & $0.45-4.80$ & 0.517 \\
\hline Minor allele frequency & 0.2161 & 0.2291 & 1.07 & $0.70-1.66$ & 0.732 & & & \\
\hline \multicolumn{9}{|l|}{ Lys939Gln } \\
\hline \multicolumn{9}{|l|}{ Additive model } \\
\hline Lys/Lys & 31 & 30 & 1.0 & - & - & 1.0 & - & - \\
\hline Lys/Gln & 58 & 61 & 1.08 & $0.58-2.01$ & 0.792 & 1.04 & $0.54-1.99$ & 0.899 \\
\hline $\mathrm{G} \ln / \mathrm{Gln}$ & 29 & 29 & 1.03 & $0.50-2.12$ & 0.929 & 0.84 & $0.39-1.78$ & 0.656 \\
\hline \multicolumn{9}{|l|}{ Dominant model } \\
\hline Lys/Lys & 31 & 30 & 1.0 & - & - & 1.0 & - & - \\
\hline Lys/Gln + Gln/Gln & 87 & 90 & 1.06 & $0.59-1.91$ & 0.822 & 0.97 & $0.52-1.79$ & 0.927 \\
\hline \multicolumn{9}{|l|}{ Recessive model } \\
\hline Lys/Lys + Lys/Gln & 89 & 91 & 1.0 & - & - & 1.0 & - & - \\
\hline $\mathrm{G} \ln / \mathrm{G} \ln$ & 29 & 29 & 0.98 & $0.54-1.76$ & 0.941 & 0.82 & $0.44-1.52$ & 0.528 \\
\hline Minor allele frequency & 0.4915 & 0.4958 & 1.01 & $0.71-1.45$ & 0.925 & & & \\
\hline
\end{tabular}

*Adjusted ORs for age of participants 
cases and the control subjects. For the Ala499Val, PAT, and Lys939Gln polymorphisms, the minor alleles showed $0.2161,0.4788$, and 0.4915 in the control group, respectively. Our statistical analysis indicated that there was very high similarity between the observed genotypic frequencies and the expected frequencies according to the HWE distribution in the controls (For Ala499Val polymorphism: $\chi^{2}=0.07, \mathrm{df}=1, P=0.781$; For PAT polymorphism: $\chi^{2}=$ $0.122, \mathrm{df}=1, P=0.726$; For Lys939Gln polymorphism: $\chi^{2}$ $=0.03, \mathrm{df}=1, P=0.856)$. Our present data revealed that there was no significant relationship between the XPC polymorphisms and the risk of ARMD (Table 2).

Statistical analysis demonstrated extremely high level of linkage disequilibrium between the XPC polymorphisms (Table 3). The haplotypic frequency in the ARMD cases and the controls are given in Table 4. The frequency of the haplotypes "Ala + Gln," "Ala - Lys," "Val - Lys," and "Ala - Gln" were 113, 69, 51, and 3 in the control group and were $118,66,55$, and 1 in the ARMD group, respectively. The "Ala + Gln" haplotype was more common compared to the other haplotypes we used as reference group $(\mathrm{OR}=1.0)$. Statistical analysis showed no relationship between the haplotypes and the susceptibility to ARMD (Table 4).

\section{Discussion}

Similar to numerous epidemiologic studies [27, 28], we found that the risk of ARMD has strong associations with cigarette smoking and outdoor workplace. When considering the occupationally sunlight exposure and smoking habit (risk factors for ARMD), it becomes apparent that these factors have well-documented effects on oxidative stress and its consequent inflammation. Moreover, oxidative stress has a variety of consequences that can affect disease progression through numerous avenues [29].

Table 3 Linkage disequilibrium between Ala499Val, PAT, and Lys939Gln polymorphisms of XPC among healthy controls and age-related macular degeneration patients

\begin{tabular}{|c|c|c|c|}
\hline Polymorphisms & Ala499Val & PAT & Lys939GIn \\
\hline Ala499Val & - & $\begin{array}{l}D^{\prime}=1.0 \\
r^{2}=0.2533 \\
X^{2}=59.77 \\
P=1.0 \times 10^{-14}\end{array}$ & $\begin{array}{l}D^{\prime}=1.0 \\
r^{2}=0.2665 \\
x^{2}=62.89 \\
P=2.1 \times 10^{-15}\end{array}$ \\
\hline PAT & $\begin{array}{l}D^{\prime}=1.0 \\
r^{2}=0.2875 \\
x^{2}=69.01 \\
P=9.7 \times 10^{-17}\end{array}$ & - & $\begin{array}{l}D^{\prime}=1.0 \\
r^{2}=0.9504 \\
x^{2}=224.28 \\
P=1.0 \times 10^{-50}\end{array}$ \\
\hline Lys939GIn & $\begin{array}{l}D^{\prime}=1.0 \\
r^{2}=0.2924 \\
X^{2}=70.17 \\
P=5.4 \times 10^{-17}\end{array}$ & $\begin{array}{l}D^{\prime}=1.0 \\
r^{2}=0.9835 \\
x^{2}=236.03 \\
P=2.8 \times 10^{-53}\end{array}$ & - \\
\hline
\end{tabular}

The upper and lower parts of the table showed parameters among healthy controls and age-related macular degeneration patients, respectively
Table 4 The association between the haplotypes of the studied XPC polymorphisms and the risk of age-related macular degeneration

\begin{tabular}{|c|c|c|c|c|c|c|c|}
\hline & Polymorphisms & & Controls & Cases & OR & $95 \% \mathrm{Cl}$ & $P$ \\
\hline 499 & PAT & 939 & & & & & \\
\hline Ala & + & Gln & 113 & 118 & 1.0 & - & - \\
\hline Ala & - & Lys & 69 & 66 & 0.91 & $0.59-1.40$ & 0.686 \\
\hline Val & - & Lys & 51 & 55 & 1.03 & $0.65-1.63$ & 0.891 \\
\hline Ala & - & Gln & 3 & 1 & 0.31 & $0.03-3.11$ & 0.326 \\
\hline
\end{tabular}

The frequencies of the 499Val, PAT-, and 939Gln alleles in our control samples were similar to the Caucasian populations [12] and our previous reports from Iran $[16,17]$. The XPC Ala499Val, PAT, and Lys939Gln polymorphisms showed linkage disequilibrium in both patient and control groups, as reported in previous reports $[12,17]$. We observed only four haplotypes ("Ala + Gln," "Ala - Lys," "Val - Lys," and "Ala - Gln") out of nine expected haplotypes among our participants, due to linkage disequilibrium in Iranian gene pool. The prevalence of four haplotypes is similar to our previous reports from Iran [17].

Previous studies have indicated that the impaired efficacy of cellular DNA repair may contribute to the pathogenesis of ARMD [5-7]. The XPC is involved in the first step of global genome nucleotide excision DNA repair pathway [8]. Considering that the Ala499Val, Lys939Gln, and PAT polymorphisms are associated with cellular DNA repair capacity [11], we hypothesized that the above-mentioned genetic variations might be involved in pathogenesis of ARMD. However, our present findings indicate that the studied genetic polymorphisms are not significantly associated with the risk of ARMD.

As we know, there are two types of ARMD. The patients included in the present study had exudative AMRD. It has been reported that a genetic polymorphism may be associated with a specific type of a multifactorial trait. For example, several genetic polymorphisms affect the risk of early or late onset bipolar disorder type 1 in different manners [30-32]. It is suggested that there is the same story for association between $X P C$ polymorphisms and dry or exudative AMRD. It should be noted that among the known genetic variations, the polymorphisms of complement factor $\mathrm{H}(C F H)$ contribute to more than $50 \%$ of disease risk, which is the first major disease-related gene for ARMD [33]. In the present study, we did not determine the $C F H$ genotypes. It should be noted that this may mask the effect of XPC polymorphisms. Further studies are needed to investigate the synergistic effect of common polymorphisms in $X P C$ and $C F H$ on predisposition to ARMD.

Considering the limited sample size in the present case-control study, further larger scaled and well- 
designed studies are needed to confirm our results, and before the final conclusion regarding the involvement of the common XPC polymorphisms in age-related macular degeneration can be drawn.

\section{Conclusions}

In the present case-control study, the association between three common XPC genetic variations and the risk of ARMD was evaluated. No significant relationship was found between the genotypes of each XPC polymorphisms and the risk of ARMD. There was also no association between the haplotypes of the study polymorphisms and the risk of ARMD.

\section{Abbreviations}

ARMD: Age-related macular degeneration; HWE: Hardy-Weinberg equilibrium; OR: Odds ratio; ROS: Reactive oxygen species; $\mathrm{CFH}$ : Complement factor $\mathrm{H}$; $\mathrm{Cl}$ : Confidence intervals; XPC: Xeroderma pigmentosum complementation group

\section{Acknowledgements}

The authors are indebted to the participants for their close cooperation. We are thankful to Dr. Majid Farvardin-Jahromi for introducing the participants. This study was supported by Shiraz University, Iran (97GCU1M1741).

\section{Authors' contributions}

MS designed the research; SK performed genotyping; SK and MS performed the statistical analyses; SK and MS interpreted the results. All authors read and approved the final manuscript.

\section{Funding}

None

\section{Availability of data and materials}

The datasets used and/or analyzed during the current study are available from the corresponding author on reasonable request.

\section{Ethics approval and consent to participate}

This study is approved by the ethics committee of Shiraz University (Iran). A written informed consent form was obtained from each patient according to the Declaration of Helsinki.

\section{Consent for publication}

Consent to publish the data was obtained from all individual participants or their attendants included in the study.

\section{Competing interests}

The authors declare that they have no conflict of interest.

Received: 16 November 2019 Accepted: 15 April 2020

Published online: 29 April 2020

\section{References}

1. Kaarniranta K, Pawlowska E, Szczepanska J, Jablkowska A, Blasiak J (2019) Role of mitochondrial DNA damage in ROS-mediated pathogenesis of agerelated macular degeneration (AMD). Int J Mol Sci 20:10. https://doi.org/10. 3390/ijms20102374

2. Bellezza I (2018) Oxidative stress in age-related macular degeneration: Nrf2 as therapeutic target. Front Pharmacol 9:1280

3. Gaillard ER, Atherton SJ, Dillon J (1995) Photophysical studies on human retinal lipofuscin. Photochem Photobiol 61:448-453

4. Strunnikova N, Zhang C, Teichberg D, Cousins SW, Baffi J, Becker KG, Csaky KG (2004) Survival of retinal pigment epithelium after exposure to prolonged oxidative injury: a detailed gene expression and cellular analysis. Invest Ophthalmol Vis Sci 45:3767-3777
5. Blasiak J, Glowacki S, Kauppinen A, Kaarniranta K (2013) Mitochondrial and nuclear DNA damage and repair in age-related macular degeneration. Int J Mol Sci 14:2996-3010

6. Lin $\mathrm{H}$, Xu H, Liang FQ, Liang H, Gupta P, Havey AN, Boulton ME, Godley BF (2011) Mitochondrial DNA damage and repair in RPE associated with aging and age-related macular degeneration. Invest Ophthalmol Vis Sci 52:35213529

7. Szaflik JP, Janik-Papis K, Synowiec E, Ksiazek D, Zaras M, Wozniak K, Szaflik J, Blasiak J (2009) DNA damage and repair in age-related macular degeneration. Mutat Res 669:169-176

8. Sugasawa K, Ng JM, Masutani C, Iwai S, van der Spek PJ, Eker AP, Hanaoka F, Bootsma D, Hoeijmakers JH (1998) Xeroderma pigmentosum group C protein complex is the initiator of global genome nucleotide excision repair. Mol Cell 2:223-232

9. Hu Z, Wang $Y$, Wang $X$, Liang G, Miao X, Xu Y, Tan W, Wei Q, Lin D, Shen H (2005) DNA repair gene XPC genotypes/haplotypes and risk of lung cancer in a Chinese population. Int J Cancer 115:478-483

10. Liu Y, Wang H, Lin T, Wei Q, Zhi Y, Yuan F, Song B, Yang J, Chen Z (2012) Interactions between cigarette smoking and XPC-PAT genetic polymorphism enhance bladder cancer risk. Oncol Rep 28:337-345

11. Zhu Y, Yang H, Chen Q, Lin J, Grossman HB, Dinney CP, Wu X, Gu J (2008) Modulation of DNA damage/DNA repair capacity by XPC polymorphisms. DNA Repair (Amst) 7:141-148

12. Sankhwar M, Sankhwar SN, Bansal SK, Gupta G, Rajender S (2016) Polymorphisms in the XPC gene affect urinary bladder cancer risk: a casecontrol study, meta-analyses and trial sequential analyses. Sci Rep 6:27018

13. Jin B, Dong Y, Zhang X, Wang H, Han B (2014) Association of XPC polymorphisms and lung cancer risk: a meta-analysis. PLoS ONE 9:e93937

14. Zhang Y, Li Z, Zhong Q, Zhou W, Chen X, Chen X, Fang J, Huang Z (2014) Polymorphisms of the XPC gene may contribute to the risk of head and neck cancer: a meta-analysis. Tumour Biol 35:3917-3931

15. Liang XH, Yan D, Zhao JX, Ding W, Xu XJ, Wang XY (2018) Interaction of polymorphisms in xeroderma pigmentosum group $C$ with cigarette smoking and pancreatic cancer risk. Oncol Lett 16:5631-5638

16. Taghipour N, Saadat I, Saadat M (2019) Association between polymorphisms of Xeroderma pigmentosum complementation group $\mathrm{C}$ gene (XPC) and susceptibility to schizophrenia. Gene 695:99-100

17. Qasemian-Talgard A, Saadat M (2020) Association between three common genetic polymorphisms of XPC and susceptibility to heroin dependency. Gene 724:144153. https://doi.org/10.1016/j.gene.2019.144153

18. Legerski RJ, Liu P, Li L, Peterson CA, Zhao Y, Leach RJ, Naylor SL, Siciliano MJ (1994) Assignment of xeroderma pigmentosum group C (XPC) gene to chromosome 3p25. Genomics 21:266-269

19. Fisher SA, Abecasis GR, Yashar BM, Zareparsi S, Swaroop A, lyengar SK, Klein BE, Klein R, Lee KE, Majewski J, Schultz DW, Klein ML, Seddon JM, Santangelo SL, Weeks DE, Conley YP, Mah TS, Schmidt S, Haines JL, PericakVance MA, Gorin MB, Schulz HL, Pardi F, Lewis CM, Weber BH (2005) Metaanalysis of genome scans of age-related macular degeneration. Hum Mol Genet 14:2257-2264

20. Chu XK, Meyerle CB, Liang X, Chew EY, Chan CC, Tuo J (2014) In-depth analyses unveil the association and possible functional involvement of novel RAD51B polymorphisms in age-related macular degeneration. Age (Dordr) 36:9627

21. Synowiec E, Wysokinski D, Zaras M, Kolodziejska U, Stoczynska-Fidelus E, Janik K, Szaflik J, Blasiak J, Szaflik JP (2014) Association between polymorphism of the DNA repair SMUG1 and UNG genes and age-related macular degeneration. Retina 34:38-47

22. Saadat I, Vakili-Ghartavol R, Farvardin-Jahromi M, Saadat M (2012) Association between exudative age-related macular degeneration and the G6721T polymorphism of XRCC7 in outdoor subjects. Korean J Ophthalmol 26:423-427

23. Blasiak J, Synowiec E, Salminen A, Kaarniranta K (2012) Genetic variability in DNA repair proteins in age-related macular degeneration. Int J Mol Sci 13: 13378-13397

24. Görgün E, Güven M, Unal M, Batar B, Güven GS, Yenerel M, Tatlipinar S, Seven M, Yüksel A (2010) Polymorphisms of the DNA repair genes XPD and $X R C C 1$ and the risk of age-related macular degeneration. Invest Ophthalmol Vis Sci 51:4732-4737

25. Tuo J, Ning B, Bojanowski CM, Lin ZN, Ross RJ, Reed GF, Shen D, Jiao X, Zhou M, Chew EY, Kadlubar FF, Chan CC (2006) Synergic effect of polymorphisms in ERCC6 5 'flanking region and complement factor $\mathrm{H}$ on 
age-related macular degeneration predisposition. Proc Natl Acad Sci U S A 103:9256-9261

26. Khan SG, Metter EJ, Tarone RE, Bohr VA, Grossman L, Hedayati M, Bale SJ, Emmert S, Kraemer KH (2000) A new xeroderma pigmentosum group C poly(AT) insertion/deletion polymorphism. Carcinogenesis 21:1821-1825

27. Willeford KT, Rapp J (2012) Smoking and age-related macular degeneration: biochemical mechanisms and patient support. Optom Vis Sci 89:1662-1666

28. Modenese A, Gobba F (2019) Macular degeneration and occupational risk factors: a systematic review. Int Arch Occup Environ Health 92:1-11

29. Shaw PX, Stiles T, Douglas C, Ho D, Fan W, Du H, Xiao X (2016) Oxidative stress, innate immunity, and age-related macular degeneration. AIMS Mol Sci 3:196-221

30. Rezaei Z, Saadat I, Saadat M (2012) Association between three genetic polymorphisms of glutathione S-transferase Z1 (GSTZ1) and susceptibility to bipolar disorder. Psychiatry Res 198:166-168

31. Mohammadynejad P, Saadat I, Ghanizadeh A, Saadat M (2011) Bipolar disorder and polymorphisms of glutathione S-transferases M1 (GSTM1) and T1 (GSTT1). Psychiatry Res 186:144-146

32. Kordestanian N, Saadat M (2017) A 50-bp Ins/Del polymorphism at the promoter region of the superoxide dismutase-1 and bipolar disorder type 1. Nord J Psychiatry 71:570-573

33. Cameron DJ, Yang Z, Gibbs D, Chen H, Kaminoh Y, Jorgensen A, Zeng J, Luo L, Brinton E, Brinton G, Brand JM, Bernstein PS, Zabriskie NA, Tang S, Constantine R, Tong Z, Zhang K (2007) HTRA1 variant confers similar risks to geographic atrophy and neovascular age-related macular degeneration. Cell Cycle 6:1122-1125

\section{Publisher's Note}

Springer Nature remains neutral with regard to jurisdictional claims in published maps and institutional affiliations.

\section{Submit your manuscript to a SpringerOpen ${ }^{\circ}$ journal and benefit from:}

- Convenient online submission

- Rigorous peer review

- Open access: articles freely available online

High visibility within the field

- Retaining the copyright to your article

Submit your next manuscript at $\boldsymbol{\nabla}$ springeropen.com 